P-ISSN: 2615-1723

E-ISSN: 2615-1766

April 2019
Jurnal Riset Pendidikan Dasar

02 (1), (2019) 54-65

Submitted: Januari, Accepted Maret, Published: April

\title{
HUBUNGAN ANTARA LEARNING STYLE DENGAN HASIL BELAJAR SISWA PADA MATA PELAJARAN MATEMATIKA KELAS V DI MIN 2 PALEMBANG
}

\author{
Mardiah Astuti, Fuaddilah Ali Sofyan, Mira Marisa \\ Program Studi Guru Madrasah Ibtidaiyah UIN Raden Fatah Palembang \\ Korespondensi. E-mail: mardiahastuti_uin@radenfatah.ac.id
}

\begin{abstract}
Abstrak
Penelitian ini bertujuan untuk mengetahui hubungan antara learning style dengan hasil belajar siswa pada mata pelajaran matematika kelas V di MIN 2 Palembang. Pendekatan dan metode penelitian ini menggunakan kuantitafif desain korelasional. Populasi dari penelitian ini adalah seluruh siswa kelas $\mathrm{V}$ yang ada di MIN 2 Palembang berjumlah 261 siswa. Sampel ditentukan dari populasi menggunakan teknik purposive sampling dengan jumlah sampel 148 siswa. Data tentang learning style dikumpulkan dari pengisian angket learning style oleh responden, sedangkan hasil belajar didapat dari hasil post-test siswa. Hasil analisis data diperoleh bahwa untuk learning style visual rhitung $(0.172)>$ rtabel $(0.1698)$, auditorial rhitung $(0.251)<$ rtabel $(0.3172)$, kinestetik rhitung $(0.127)>$ rtabel $(0.3009)$. Berdasarkan kriteria pengujian maka hipotesis nol (Ho) diterima dan hipotesis alternatif (Ha) ditolak (auditorial dan kinestetik). Jadi, dapat disimpulkan bahwa tidak terdapat hubungan yang signifikan antara learning style (auditorial dan visual) dengan hasil belajar siswa pada mata pelajaran matematika kelas V di MIN 2 Palembang.
\end{abstract}

Kata Kunci: Learning Style, Hasil Belajar Siswa

\section{RELATIONSHIP BETWEEN LEARNING STYLE WITH STUDENT LEARNING OUTCOMES IN VOCATIONAL SCHOOL OF MATHEMATICS CLASS IN MIN 2 PALEMBANG}

\begin{abstract}
This study aims to determine the correlation between learning style and student's academic achievement of mathematics the fifth grade students at MIN 2 Palembang. This types of research are quantitative, correlation design. The population of this study was 261 students and 148 were taken as the sample by purposive sampling. The data collected are the results of filling the learning style and mathematics test by the respondents. The results of data analysis obtained for visual tcount (0.172) > ttable (0.1698), while auditorial tcount $(0.251)<$ ttable $(0.3172)$, cinestethic tcount (0.127) < ttable (0.3009). Based on the criteria of test, the null hypothesis (Ho) is accepted and the alternative hypothesis $(\mathrm{Ha})$ is rejected for auditorial and cinestethic. So it can be concluded that there is no significant correlation between learning style (auditorial and cinestethic) and student's academic achievement of mathematics the fifth grade students at MIN 2 Palembang.
\end{abstract}

Keywords: Learning Style, Student Academic Achievement

Copyright $@ 2019$, JRPD, ISSN 2615 - 1723 (Print), ISSN 2615 - 1766 (Online) 


\section{Jurnal Riset Pendidikan Dasar, 02 (1), April 2019 (54-65)}

Mardiah Astuti, Fuaddilah Ali Sofyan, Mira Marisa

\section{PENDAHULUAN}

Pendidikan merupakan proses interaksi belajar mengajar yang bertujuan meningkatkan perkembangan mental sehingga menjadi mandiri dan dapat dikatakan bahwa pendidikan merupakan sebuah proses yang terjadi pada setiap individual dengan adanya perkembangan menuju kearah yang lebih dewasa.

Setiap anak merupakan individu yang unik, masing-masing akan melihat dunia dengan caranya sendiri. Meskipun melihat satu kejadian pada waktu yang bersamaan, hal tersebut tidak menjamin beberapa anak melaporkan hal yang sama. Terkadang yang menjadi pergumulan dalam dunia pendidikan bukan pada masalah "apakah anak dapat belajar?", tetapi pada masalah "bagaimana mereka secara alami belajar dengan cara terbaik mereka?".

Pada umumnya terdapat tiga tipe learning style (gaya belajar) dari seorang siswa. Pertama, yaitu visual yang mana dalam proses belajar visual siswa lebih mudah belajar dengan cara melihat atau mengamati. Kedua, auditorial dalam gaya belajar kali ini siswa lebih mudah menerima pembelajaran dengan cara mendengarkan. Ketiga, yaitu gaya belajar kinestetik yang mana siswa lebih mudah menangkap pembelajaran dengan cara melakukan. Oleh karena itu, dengan mengetahui adanya learning style yang dimiliki masing-masing siswa, guru dapat menyesuaikan learning style dengan kebutuhan siswa.

Menurut B Uno (2006) dalam buku yang berjudul "Orientasi Baru Dalam Psikologi Pembelajaran" menyebutkan apapun cara yang dipilih, perbedaan learning style (gaya belajar) itu menunjukkan cara tercepat dan terbaik bagi setiap individu untuk bisa menyerap sebuah informasi dari luar dirinya. Ada beberapa tipe learning style yang bisa diperhatikan yaitu, gaya belajar visual, gaya belajar auditorial, dan gaya belajar kinestetik.

Menurut Nasution (2009) yang dinamakan gaya belajar adalah cara yang konsisten yang dilakukan oleh seorang murid dalam menangkap stimulus atau informasi, cara mengingat, berpikir dan memecahkan soal.

Maka dari itu, learning style (gaya belajar) merupakan suatu kemampuan yang dimiliki peserta didik dalam menerima, menyerap, mengatur dan mengolah materi pelajaran yang diterimanya selama proses pembelajaran. Dengan demikian, learning style merupakan salah satu hal yang penting untuk meningkatkan hasil belajar siswa. Hal ini dikarenakan berdasarkan gambaran teori Copyright (C2019, JRPD, ISSN 2615 - 1723 (Print), ISSN 2615 - 1766 (Online) 


\section{Jurnal Riset Pendidikan Dasar, 02 (1), April 2019 (54-65)}

Mardiah Astuti, Fuaddilah Ali Sofyan, Mira Marisa

yang ada, prestasi seorang individu juga dilihat dari segi gaya belajar seorang siswa.

Penelitian ini disertai dengan adanya beberapa peneliti sebelumnya yang telah dilakukan oleh Elva Apriana 2018 Fakultas Tarbiyah dan Keguruan dengan judul skripsi "Hubungan Antara Gaya Belajar dengan Hasil Belajar Aqidah Akhlaq Siswa Kelas V Di MIN 12 Bandar Lampung”. Dari penelitian ini terlihat bahwa berdasarkan hasil analisis yang diproleh dari hasil penelitian menunjukkan bahwa dengan perhitungan koefisien korelasi (rhitung) yang diperoleh nilai sebesar 0,9134, kemudian nilai tersebut dibandingkan dengan rtabel padataraf signifikan $5 \%$ yaitu 0,413 bahwa rhitung $>$ rtabel atau 0,9134 > 0,413, sehingga hipotesis nol (Ho) ditolak dan (Ha) diterima.

Tingkat korelasi atau hubungan gaya belajar dengan hasil belajar yang dihasilkan oleh siswa dalam mata pelajaran Akidah Akhlak kelasVdi MIN 12 Bandar Lampung termasuk dalam kategori "kuat" yaitu dengan melihat rhitung $=0,9134$. Dan hasil KP (nilai koefisien determinan) pun menunjukkan bahwa gaya belajar dengan hasil belajar adalah 83,44 dan sisanya16,56 dipengaruhi oleh faktor lain.

Berdasarkan observasi yang dilakukan pada tanggal 27-Agustus-2018 di MIN 2 Palembang, peneliti melihat bahwa ketika guru mengajar belum memperhatikan keragaman learning style siswa. Hal tersebut terlihat ketika guru memilih salah satu metode dan media kurang memerhatikan learning style yang ada. Suasana belajar yang belum kondusif membuat setiap siswa acuh tak acuh pada sekitarnya. Hal tersebut akan berpengaruh pada hasil belajar siswa.

Tohirin mengatakan, bahwa hasil belajar adalah suatu hal yang telah dicapai oleh seorang siswa setelah melakukan proses pembelajaran yang dilalui dan merujuk ketiga ranah yaitu, kognitif, afektif, dan psikomotorik. Pada prinsipnya, pengungkapan hasil belajar yang ideal meliputi segenap ranah psikologis yang berubah sebagai akibat pengalaman dan proses belajar siswa. Hal ini disebabkan perubahan hasil belajar memiliki sifat intangible (tidak memiliki wujud).

Hasil belajar berkaitan dengan pencapaian dalam bentuk memperoleh kemampuan sesuai dengan kurikulum yang berlaku yang direncakan. Dengan demikian, tugas guru dilihat dari apa saja yang ada dalam kegiatan.

Dari uraian di atas dan berdasarkan hasil observasi, maka peneliti mengambil kesimpulan untuk membahas dan meneliti learning style siswa untuk menyelesaikan studinya dalam proposal dan yang akan berlanjut menjadi tugas skripsi dengan judul Copyright $@ 2019$, JRPD, ISSN 2615 - 1723 (Print), ISSN 2615 - 1766 (Online) 


\section{Jurnal Riset Pendidikan Dasar, 02 (1), April 2019 (54-65)}

Mardiah Astuti, Fuaddilah Ali Sofyan, Mira Marisa

"Hubungan Antara Learning Style Dengan Hasil Belajar Siswa Pada Mata Pelajaran Matematika Kelas V Di MIN 2 Palembang".

Berdasarkan uraian latar belakang di atas, maka yang menjadi rumusan masalah pada penelitian ini adalah "bagaimana hubungan antara learning style dengan hasil belajar siswa pada mata pelajaran matematika kelas V di MIN 2 Palembang?"

Pada rumusan masalah di atas, maka tujuan dari penelitian ini adalah untuk mengetahui tentang "hubungan antara learning style dengan hasil belajar siswa pada mata pelajaran matematika kelas V di MIN 2 Palembang'.

Manfaat yang diharapkan oleh penulis dari penelitian ini adalah bagi peneliti dapat menambah wawasan dan serta keterampilan dalam menulis, bagi guru penelitian ini dapat dijadikan acuan lebih lanjut untuk mengetahui learning style siswa dan bagi siswa penelitian ini dapat membantu siswa mengetahui learning style yang ada pada diri mereka sehingga dikemudian hari siswa mendapatkan hasil belajar yang memuaskan.

\section{METODE PENELITIAN}

Penelitian ini menggunakan pendekatan kuantitatif dan metode design korelasional. Penelitian ini dilaksanakan di
MIN 2 Palembang. Populasi penelitian ini adalah kelas V MIN 2 Palembang yang terdiri dari tujuh kelas (VA-VG). Sampel penelitian ini terdiri dari empat kelas (VDVG). Teknik penentuan sampel ini menggunakan teknik purposive sampling.

Teknik pengumpulan data dari penelitian ini menggunakan observasi, angket, tes dan dokumentasi. Observasi dilakukan untuk mengetahui karakteristik learning style siswa. Angket diberikan untuk mengetahui hasil learning style siswa. Kemudian, tes diberikan untuk mengetahui hasil belajar siswa dan dokumentasi dilakukan untuk mengetahui informasi tempat penelitian. Kemudian, setelah data telah dijawab oleh responden maka seluruh data diolah dengan tahapan analisis data kuantitatif yaitu korelasi product moment dengan menggunakan program SPSS Seri 16.

\section{HASIL DAN PEMBAHASAN}

Bagian ini akan menjawab masalah penelitian dengan menganalisis hasil statistik hubungan antara learning style dengan hasil belajar siswa. Berdasarkan korelasi koefisien product moment. Hasilnya menunjukkan bahwa hubungan antara learning style dengan hasil belajar siswa adalah positif untuk visual serta negatif untuk auditorial dan kinestetik. Hal tersebut Copyright $\odot 2019$, JRPD, ISSN 2615 - 1723 (Print), ISSN 2615 - 1766 (Online) 
dilihat dari hasil perhitungan rhitungdan rtabel. Kemudian di tingkat signifikan (sig. 2 tailed) dilihat dari perhitungan rhitung 0.05. dengan demikian, tidak terdapat hubungan yang positif dan negatif untuk kedua variabel.

\section{Hasil dan Pembahasan Penelitian} Learning Style (Visual) Siswa
Dari hasil uji normalitas diketahui bahwa pada taraf signifikasi learning stylevisual rhitung $0.128>0.05$ dan hasil belajar (post-test) siswa rhitung 0.295>0.05. Oleh karena itu, dapat disimpulkan bahwa dari kedua variabel tersebut data berdistribusi normal. Hal ini ditunjukkan dengan adanya Q-Q Plot (penyebaran data) pada grafik 1 dan 2 .

\section{Normal Q-Q Plot of Visual}

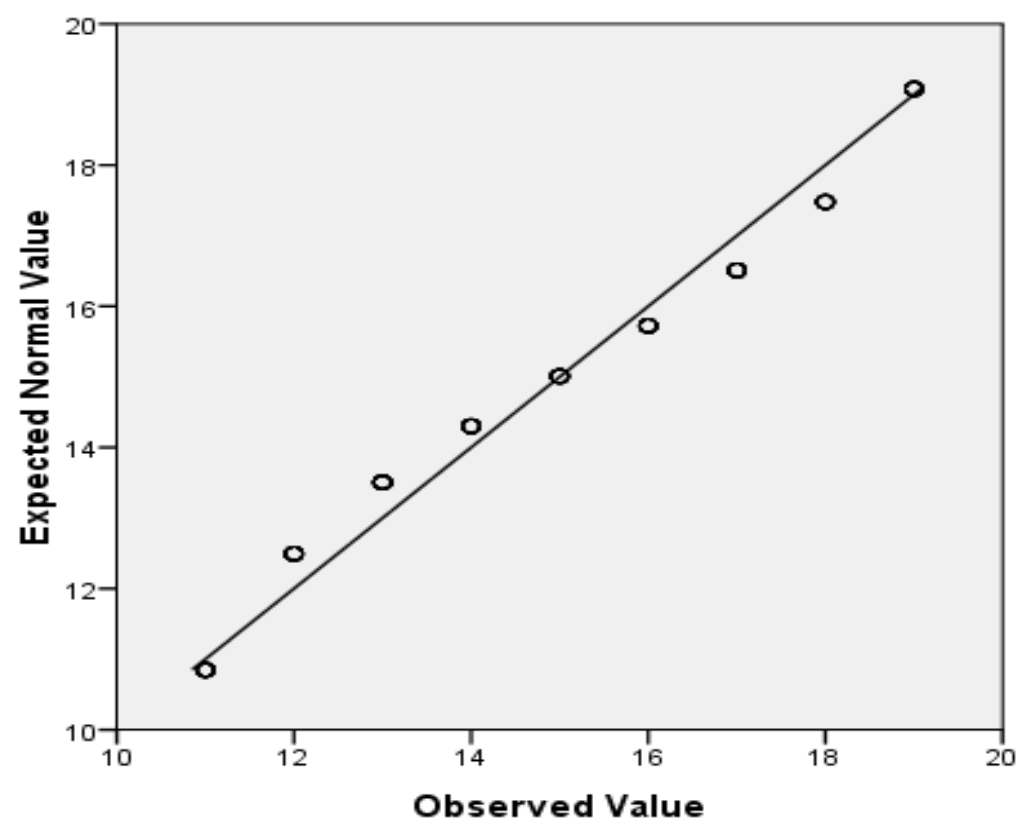

Gambar 1 Data Distribusi Normal Q-Q Plot Learning Style (Visual) Siswa 


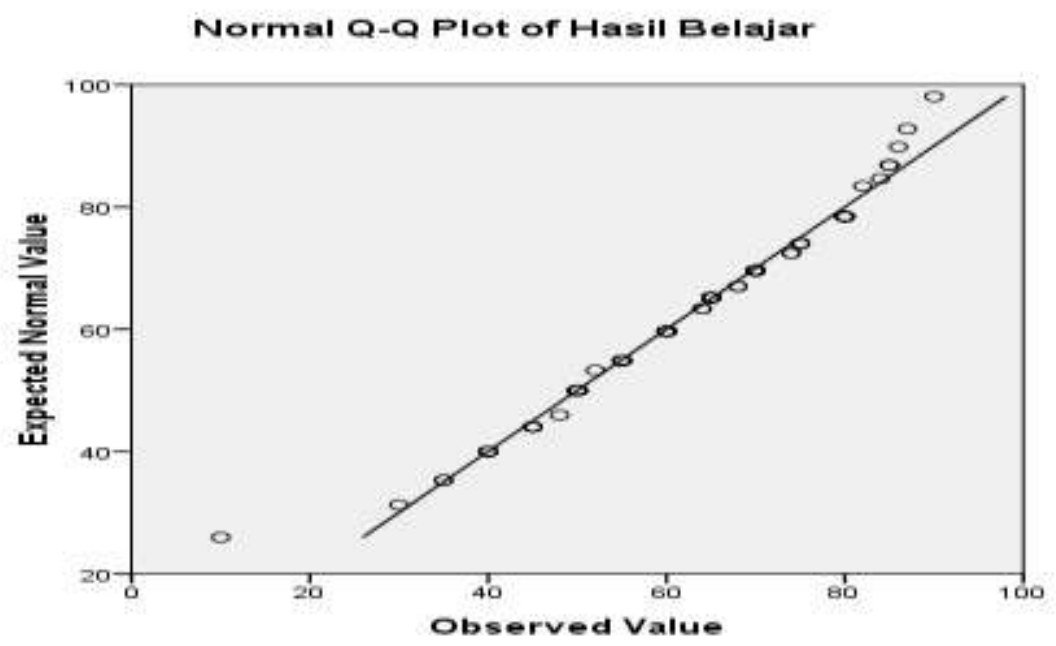

Gambar 2 Data Distribusi Normal Q-Q Plot Hasil Belajar Siswa

Berdasarkan korelasi koefisien perhitungan bahwa rhitung $(0.172)>$ rtabel product moment. Hasilnya menunjukkan (0.1698). Kemudian di tingkat signifikan bahwa hubungan antara learning (sig. 2 tailed) adalah rhitung $0.031<0.05$. style(visual) dengan hasil belajar siswa dengan demikian, terdapat hubungan yang adalah positif. Hal tersebut dilihat dari hasil signifikan antara kedua variabel.

\section{Correlations}

\begin{tabular}{|cc|c|c|}
\hline & & Visual & Hasil Belajar \\
\hline Visual & Pearson Correlation & 1 & .172 \\
& Sig. (2-tailed) & & .031 \\
& $\mathrm{~N}$ & 93 & 93 \\
\hline Hasil Belajar & Pearson Correlation & .172 & 1 \\
& Sig. (2-tailed) & .031 & \\
& $\mathrm{~N}$ & 93 & 93 \\
\hline
\end{tabular}

Hasil dan Pembahasan Penelitian Learning

\section{Style (Auditorial) Siswa}

Dari hasil uji normalitas diketahui bahwa pada taraf signifikasi learning styleauditorialrhitung $0.345>0.05$ dan hasil belajar (post-test) siswa rhitung 0.564>0.05.
Oleh karena itu, dapat disimpulkan bahwa dari kedua variabel tersebut data berdistribusi normal. Hal ini ditunjukkan dengan adanya Q-Q Plot (penyebaran data) pada grafik 4.3 dan 4.4

$$
\text { Copyright } @ 2019 \text {, JRPD, ISSN } 2615 \text { - } 1723 \text { (Print), ISSN } 2615 \text { - } 1766 \text { (Online) }
$$




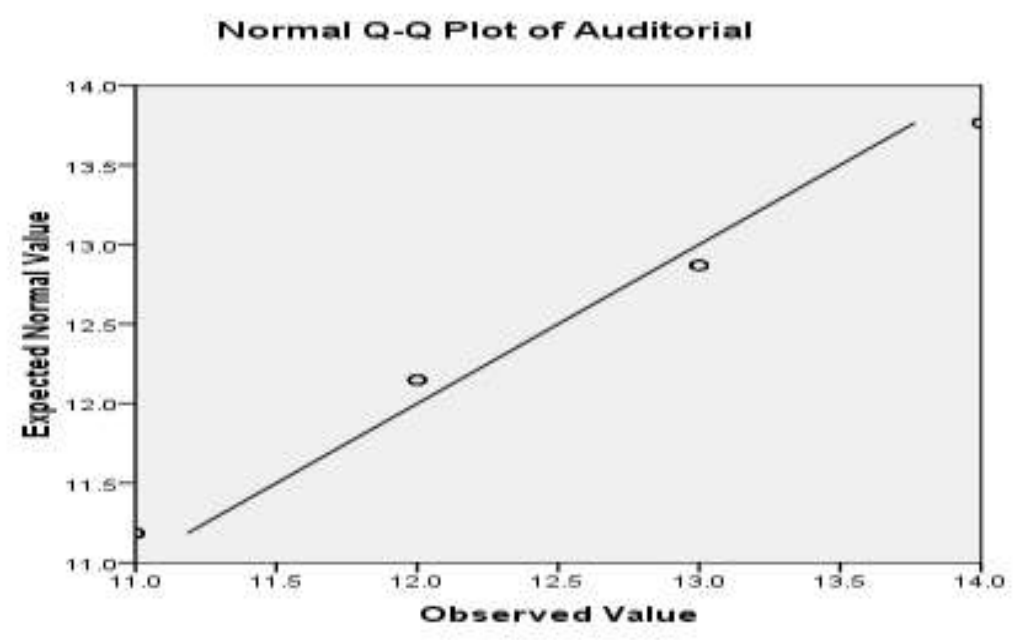

Gambar 3 Data Distribusi Normal Q-Q Plot Learning Style (Auditorial) Siswa

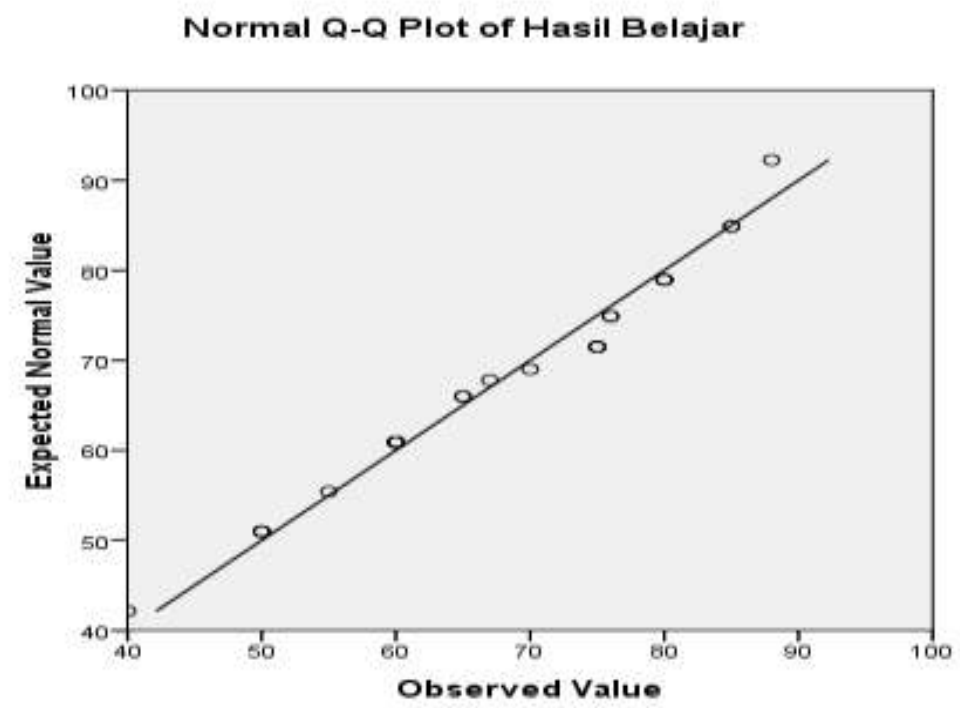

Gambar 4 Data Distribusi Normal Q-Q Plot Hasil Belajar Siswa

Berdasarkan korelasi koefisien bahwa rhitung (0.251) < rtabel (0.3172). product moment. Hasilnya menunjukkan Kemudian di tingkat signifikan (sig. 2 bahwa hubungan antara learning style tailed) adalah rhitung 0.217>0.05. dengan (auditorial) dengan hasil belajar siswa demikian, tidak terdapat hubungan yang adalah negatif (tidak berhubungan). Hal signifikan antara kedua variabel. tersebut dilihat dari hasil perhitungan 


\begin{tabular}{|cc|c|c|}
\hline & & Auditorial & Hasil Belajar \\
\hline Auditorial & $\begin{array}{c}\text { Pearson } \\
\text { Correlation }\end{array}$ & 1 & -.251 \\
& Sig. (2-tailed) & & .217 \\
& $\mathrm{~N}$ & 26 & 26 \\
\hline Hasil Belajar & Pearson & -.251 & 1 \\
& Correlation & & \\
& Sig. (2-tailed) & .217 & 26 \\
& $\mathrm{~N}$ & 26 & 26 \\
\hline
\end{tabular}

Hasil dan Pembahasan Penelitian Learning Style (Kinestetik) Siswa

Dari hasil uji normalitas diketahui bahwa pada taraf signifikasi learning stylekinestetik rhitung $0.345>0.05$ dan hasil belajar (post-test) siswa rhitung $0.564>0.05$.
Oleh karena itu, dapat disimpulkan bahwa dari kedua variabel tersebut data berdistribusi normal. Hal ini ditunjukkan dengan adanya Q-Q Plot (penyebaran data) pada grafik 4.5 dan 4.6

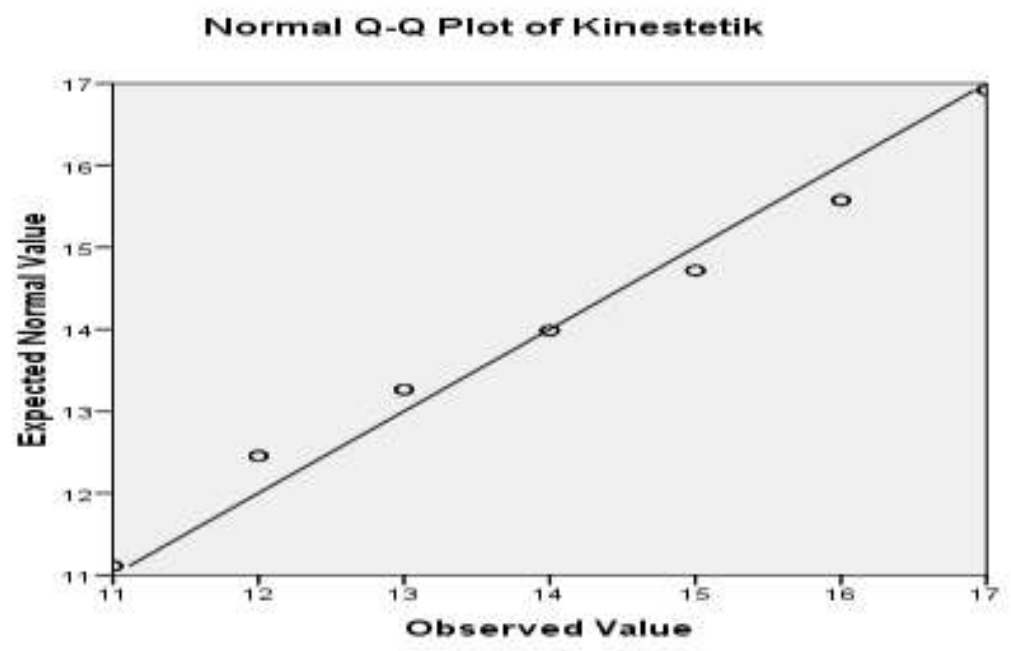

Gambar 5 Data Distribusi Normal Q-Q Plot Learning Style (Kinestetik) Siswa 
Jurnal Riset Pendidikan Dasar, 02 (1), April 2019 (54-65)

Mardiah Astuti, Fuaddilah Ali Sofyan, Mira Marisa

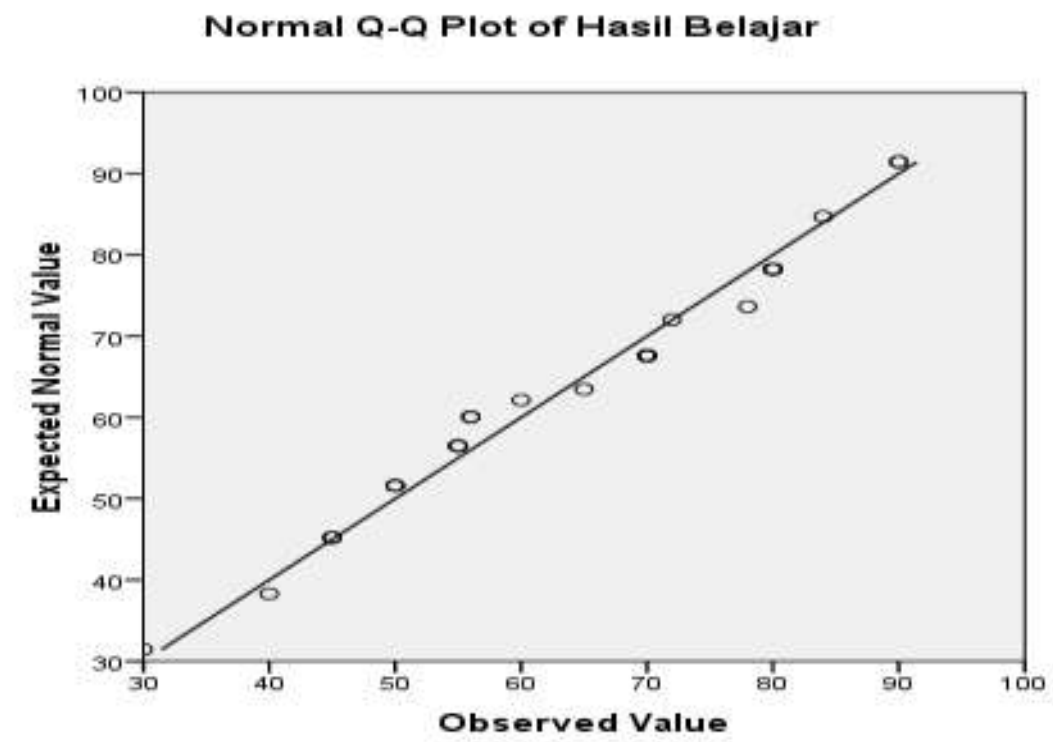

Gambar 6 Data Distribusi Normal Q-Q Plot Hasil Belajar Siswa

Berdasarkan korelasi koefisien bahwa rhitung $(0.127)<$ rtabel $(0.3009)$. product moment. Hasilnya menunjukkan Kemudian di tingkat signifikan (sig. 2 bahwa hubungan antara learning style tailed) adalah rhitung $0.513>0.05$. dengan (kinestetik) dengan hasil belajar siswa demikian, tidak terdapat hubungan yang adalah negatif (tidak berhubungan). Hal signifikan antara kedua variabel. tersebut dilihat dari hasil perhitungan

\begin{tabular}{|c|c|c|c|}
\hline & & Kinestetik & Hasil Belajar \\
\hline \multirow[t]{3}{*}{ Kinestetik } & $\begin{array}{l}\text { Pearson } \\
\text { Correlation }\end{array}$ & 1 & .127 \\
\hline & Sig. (2-tailed) & & .513 \\
\hline & $\mathrm{N}$ & 29 & 29 \\
\hline \multirow[t]{3}{*}{ Hasil Belajar } & $\begin{array}{l}\text { Pearson } \\
\text { Correlation }\end{array}$ & .127 & 1 \\
\hline & Sig. (2-tailed) & .513 & \\
\hline & $\mathrm{N}$ & 29 & 29 \\
\hline
\end{tabular}

Copyright (C2019, JRPD, ISSN 2615 - 1723 (Print), ISSN 2615 - 1766 (Online) 
Berdasarkan hasil data yang didapat antara variabel (x) dan variabel (y) keduanya tidak memiliki hubungan. Oleh karena itu, peneliti menambahkan beberapa penelitian terdahulu yang dapat dijadikan bahan rujukan dan pertimbangan dengan menunjukkan bahwa learning style dengan hasil belajar siswa tidak memiliki hubungan.

Komang Ngurah Wiyasa (2017) Fakultas Ilmu Keguruan dan Pendidikan dengan judul skripsi "Korelasi Antara Gaya Belajar Dengan Penguasaan Kompetensi Pengetahuan IPS Siswa Kelas V SD Gugus 1 Kecamatan Mengwi" menunjukkan bahwa berdasarkan jenis data yang dikumpulkan dapat diketahui data yang diperoleh yakni rhitung $=1,228$ dengan rtabel 1,980 yang berarti rhitung < rtabel sehingga Ho diterima dan $\mathrm{Ha}$ ditolak, dan disimpulkan bahwa tidak terdapat hubungan yang signifikan antara gaya belajar dengan penguasaan kompetensi pengetahuan IPS siswa.

Dari penelitian ini terdapat perbedaan dan persamaan. Perbedaannya bhawa penelitian yang dilakukan Komang Ngurah Wiyasa berujuk pada pemahaman komptensi pengetahuan IPS siswa, bukan mengarah pada hasil belajar siswa. Dan persamaannya bahwa peneliti melakukan penelitian dengan pendekatan dan metode yang sama yakni kuantitatif desain korelasional.
Istamar Syamsuri (2016) FMIPA dengan judul tesis "Hubungan Antara Gaya Belajar Dengan Hasil Belajar Siswa SMA Berbasis Skor Selisih Dalam Pembelajaran Biologi Pada Pembelajaran Group Investigation (GI) Di Kota Malang" berdasarkan hasil analisis data, dapat diketahui bahwa tidak ada hubungan antara lgaya belajar berbasis skor selisih dengan hasil belajar yang dicapai.

Hal ini menunjukan bahwa semua gaya belajar yang dimiliki oleh masingmasing siswa mempunyai peluang yang sama untuk memperoleh hasil belajar yang baik. Hasil analisis data mengenai gaya belajar siswa diperolehdari data angket gaya belajar yang diisi oleh responden dimana pada hasil post-test menyatakan bahwa dari 65 orang 53,58\% siswa memiliki gaya belajar visual, $20,76 \%$ siswa memiliki gaya belajar audio dan 15,38\% siswa memiliki gaya belajar kinestetik. Setelah penerapan metode pembelajaran group investigation hasil penelitian menyatakan $60 \%$ siswa memiliki gaya belajar visual, 27,69\% siswa memiliki gaya belajar audio dan 12,30\% siswa memiliki gaya belajar kinestetik (Syamsuri, 2016).

Dalan penelitian terdapat perbedaan dan persamaan terhadap penelitian yang dilakukan. Perbedaannya terletak bahwa penelitian ini terdiri dari tiga variabel. Dan persamaan terhadap penelitian yang Copyright (C2019, JRPD, ISSN 2615 - 1723 (Print), ISSN 2615 - 1766 (Online) 


\section{Jurnal Riset Pendidikan Dasar, 02 (1), April 2019 (54-65)}

Mardiah Astuti, Fuaddilah Ali Sofyan, Mira Marisa

dilakukan yaitu mencari tingkat Danarjati, D, P. (2014). Psikologi korelasional antara variabel.

Pendidikan. Yogjakarta: Bumi Aksara.

\section{SIMPULAN}

Setelah dilakukan analisis data pada bab IV, diketahui bahwa dari kedua variabel tersebut Ho diterima sedangkan Ha ditolak (auditorial dan kinestetik). Itu artinya, bahwa tidak hasil analisis data kedua variabel tersebut tidak berkorelasi. Hal ini berdasarkan bahwa dari hasil perhitungan bahwa learning stylevisual rhitung (0.172) > rtabel (0.1698).auditorial rhitung $(0.251)<$ rtabel (0.3172), kinestetik rhitung (0.127) <rtabel (0.3009). Dengan demikian, terdapat hubungan yang positif dan negatif untuk kedua variabel tersebut dengan hasil belajar siswa.

\section{DAFTAR PUSTAKA}

Agustina, R. (2017). "Hubungan Antara Gaya Belajar Dengan Hasil Belajar Pada Mata Pelajaran IPA kelas IV MI Ma'had Islami Palembang". Fakultas Ilmu Tarbiyah dan Keguruan, Palembang: UIN Raden Fatah.

Arikunto, S. (2014). Prosedur Penelitian. Jakarta: Rineka cipta.
Deporter, B., \& Mike, H. (2015). Quantum Learning Membiasakan Belajar Nyaman dan Menyenangkan. Bandung: Kaifa

Febrikan, E.I. 2015. "Hubungan Antara Gaya Belajar dengan Prestasi Belajar Siswa". Fakultas Keguruan dan Ilmu Pendidikan, Bandar Lampung: Universitas Lampung.

Ghufran, M.N. (2014). Gaya Belajar "Kajian Teoritik". Yogjakarta: Pustaka Pelajar.

Havis M. (2015). "Hubungan A1 Gaya Belajar Dengan Hasil Belugw Jiswa Pada Pembelajaran Biologi Kela X SMAN 2 Sungai Tarab Kabupaten Tanah Datar" Fakultas Ilmu Tarbiyah dan Keguruan, Batusangkar: IAIN Batusangkar.

Ismail, F. (2014). Evaluasi Pendidikan. Palembang: Tunas Gemilang Press. Nasution. (2009). Berbagai Pendekatan dalam Proses Belajar dan Mengajar. Jakarta: PT. Bumi Aksara.

Syah, M. (2015). Psikologi Belajar. Jakarta: PT. Raja Grafindo Pers.

Syaifurrahman \& Tri Ujiati. (2013). Manajemen Dalam Pembelajaran. Jakarta: Indeks. 
Jurnal Riset Pendidikan Dasar, 02 (1), April 2019 (54-65)

Mardiah Astuti, Fuaddilah Ali Sofyan, Mira Marisa

Syamsuri, I. (2016). "Hubungan Antara Sudijono, A. (2014). Pengantar Statistik Gaya Belajar Dengan Hasil Belajar Siswa SMA Berbasis Skor Selisih Pendidikan. Jakarta: PT. Dalam Pembelajaran Biologi Pada Pembelajaran Group Investigation (GI) RajaGrafindo Persada.

Di Kota Malang'FMIPA, Malang: Sugiyono. (2016). Metode Penelitian Universitas Negeri Malang. Kuantitatif, Kualitatif, dan $R \& D$. Bandung:Alfabeta 